\title{
Business Cycles and the Eighth District
}

\section{G. J. SANTONI}

UESTIONS frequently arise regarding the longer-run economic performance of a particular geographic region relative to the nation as a whole. Recently, for example, attention has been focused on the rapid growth of the "Sun Belt" states and the economic decline of the industrial centers in the Northeast. Fundamental economic forces, of course, are always at work and over long time periods can have substantial effects on the economic growth of a particular region. ${ }^{\text {I }}$

Alternatively, questions about the relative performance of a particular region may focus on shorter-run issues. Economic conditions in the Eighth Federal Reserve District, for example, have drawn considerable attention during the recent recession. Various commentators have pointed out that the recession was particularly severe, resulting in a decline in District economic activity relative to the nation. This differential effect apparently has been most noticeable in the markets for consumer goods, labor, transportation and residential housing. ${ }^{2}$ In addition, some observers have claimed that the recession caused the growth rates of District personal income and tax revenues to decline relative to national averages. ${ }^{3}$

G. J. Santoni is a senior economist at the Federal Reserve Bank of St. Louis. Thomas A. Pollmann provided research assistance.

${ }^{1}$ See, for example, Mancur Olson, "The South Will Fall Again: The South as Leader and Laggard in Economic Growth," Southern Economic Journal (April 1983). pp. 917-32, Mancur Olson, The Rise and Decline of Nations: Economic Growth, Stagflation, and Social Rigidities (Yale University Press, 1982); and R. Alton Gilbert, "Employment Growth in St. Louis," this Review (August 1973), pp. 2-15.

${ }^{2}$ See, for example, "Memphis Falls Behind on Buying-Power List," Memphis Commercial Appeal, September 2, 1983; "River Shipping In Troubled Waters" " $5 t$. Louts Post-Dispatch, Wuly 25, 1983 ; "Market For Homes Is Termed Healthy," Memphis Commercial Appeal, September 4, 1983; Bill Kester, "St. Louis Economy Lags U.S. Economic Recovery," St. Louis Post-Dispatch, September 7, 1983.

"Kentuckians Earn Less Than National Average," Louisville Courier Journal, September 6, 1983; and "State In Financial Bind, Consultant Says," Louisville Coturier Journal, July $29,1983$.
If the relatively poor economic performance of the District during the recent recession was a capricious event, it would be useless to worry about. The observed discrepancy may have been a mere statistical artifact that has no lasting importance. A similar situation may never arise again and it would be unprofitable to alter present plans (which, presumably, are based on expected future circumstances) to take account of an event that is not expected to recur.

The purpose of this article is to assess whether economic conditions in the Eighth District typically follow those of the nation or whether there is a consistently different pattern to local economic fluctuations when compared with national trends. If, as some commentators have suggested, there are important differences between business conditions in the Eighth District and those in the rest of the country, it would be of interest to determine what the reasons for such disparate behavior might be and what, if anything, can be done about them.

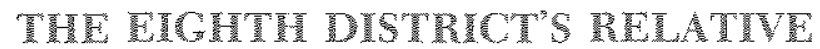 PENTOPMANCE DUPING THE 1980}

Table 1 presents the average growth rate of personal income, total employment, the total dollar value of residential and commercial construction, housing starts, mortgage loans and the level of the unemployment rate in the United States and the District during the recent recession (the third quarter of 1981 to the fourth quarter of 1982) and the previous expansion (the third quarter of 1980 to the second quarter of 1981). ${ }^{4}$

\footnotetext{
"The Eighth Federal Reserve District includes Arkansas, parts of Missouri, Ilinois, Indiana, Mississippi, Kentucky and Tennessee. Since data by county are not available in a convenient form and since the bulk of the economic activity in the District is accounted for by the states of Arkansas, Kentucky, Missouri and Tennessee, fable 1 and subsequent tables include data for these states only.
} 


\section{Table 1}

\section{Growth Rates and Levels of Selected Economic Indicators}

\begin{tabular}{|c|c|c|c|}
\hline & \multicolumn{3}{|c|}{ Avorage } \\
\hline & Distre & 10 & Difierence \\
\hline \multicolumn{4}{|c|}{ recent recession ill got, WW1982 } \\
\hline \multicolumn{4}{|l|}{ Growh rates } \\
\hline Pessonal reone & $566 \%$ & 6.848 & $0.95 \%$ \\
\hline Tolal enplopinent & 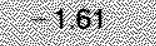 & 20.68 & 1009 \\
\hline 1oral bulding & 103 & 4.09 & 5,12 \\
\hline Noinsing starts & 4.66 & 176 & 643 \\
\hline Morgage loans & 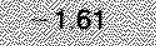 & 2.69 & 0.48 \\
\hline \multicolumn{4}{|l|}{ Lever } \\
\hline Unemploymertitus & 964 & 866 & 76 \\
\hline \multicolumn{4}{|c|}{ Previous Expansion 111960-111981. } \\
\hline \multicolumn{4}{|l|}{ Orowh rates } \\
\hline Cersonal nowne & $964 \%$ & $10.40 \%$ & $0.85 \%$ \\
\hline rotar employnen & 0.63 & 0.80 & 1,28 \\
\hline Tota biving & 48.70 & 2427 & 19.46 \\
\hline Howsing stans. & 16.88 & 796 & 1708 \\
\hline Mortgage baans & 374 & 5.60 & 1.66 \\
\hline Level & & & 2 \\
\hline Unemploymertiate & 8.10 & 744 & 0.66 \\
\hline
\end{tabular}

Some of the differences appear, at first blush, to be substantial. The personal income of District residents grew at an average rate that was roughly 1 percent below the national growth rate during both the recession and the previous expansion. This was true, as well, for the growth rate in total employment. The unemployment rate in the District was about three-fourths of a percent higher. The growth rate in the total dollar value of residential and commercial construction (total building) was 5.12 percent lower than the national average during the contraction. With the exception of housing starts and mortgage loans during the recession and total building during the expansion, economic growth in the District was depressed relative to the national average during both the recent contraction and prior expansion.

Because these differences are based on relatively few observations, they can be misleading. A more reliable inference can be drawn by examining the economic performance of the District relative to the nation over a number of business cycles. If the results are similar to those of table 1 , we can be more confident that the experience of 1981-82 was not freakish.

\section{ECONOMIC ACTIVTY IN THE EICHTI DISTRICT RELATIVE TO THE NATION}

\section{The Period 1970-83}

Chart I plots the quarterly growth rates of personal income, total employment, total building, housing starts, mortgage loans and the level of unemployment for the Eighth District and the United States from the first quarter of 1970 through the first quarter of 1983. The shaded areas represent periods of recession, while the horizontal lines indicate the averages for the entire period.

One interesting feature of this chart is that the averages of the various growth rates for the District appear to correspond closely to their respective national averages. Statistical testing confirms this observation, as the data in table 2 demonstrate. Although the differences between the average growth rates fluctuate between -1.47 and 0.23 , depending upon the specific indicator selected, none is statistically significant.

The average level of the unemployment rate, however, is an exception to the general observation regarding the growth rates. On average, the District's unemployment rate is about 0.5 percent below the national average and this difference is statistically significant. In terms of the level of unemployment, the District, on average, has outperformed the nation.

The data in table 2 also help explain the differences between District and national indicators when the sample is small as in table 1 . Notice that the variances of the growth rates and unemployment rate generally are higher for the District than they are for the nation (see table 2). Moreover, District variances for the growth rates of personal income, total employment, total building and the level of unemployment are significantly higher in a statistical sense. This means that these District indicators of economic activity are more volatile than the national indicators. If, as seems to be the case, the true averages of the respective indicators do not differ between the District and the nation, it is likely that for small samples there will appear to be substantial differences between District and national 
Selected Economic Indicators in the United States and the Eighth Federal Reserve District
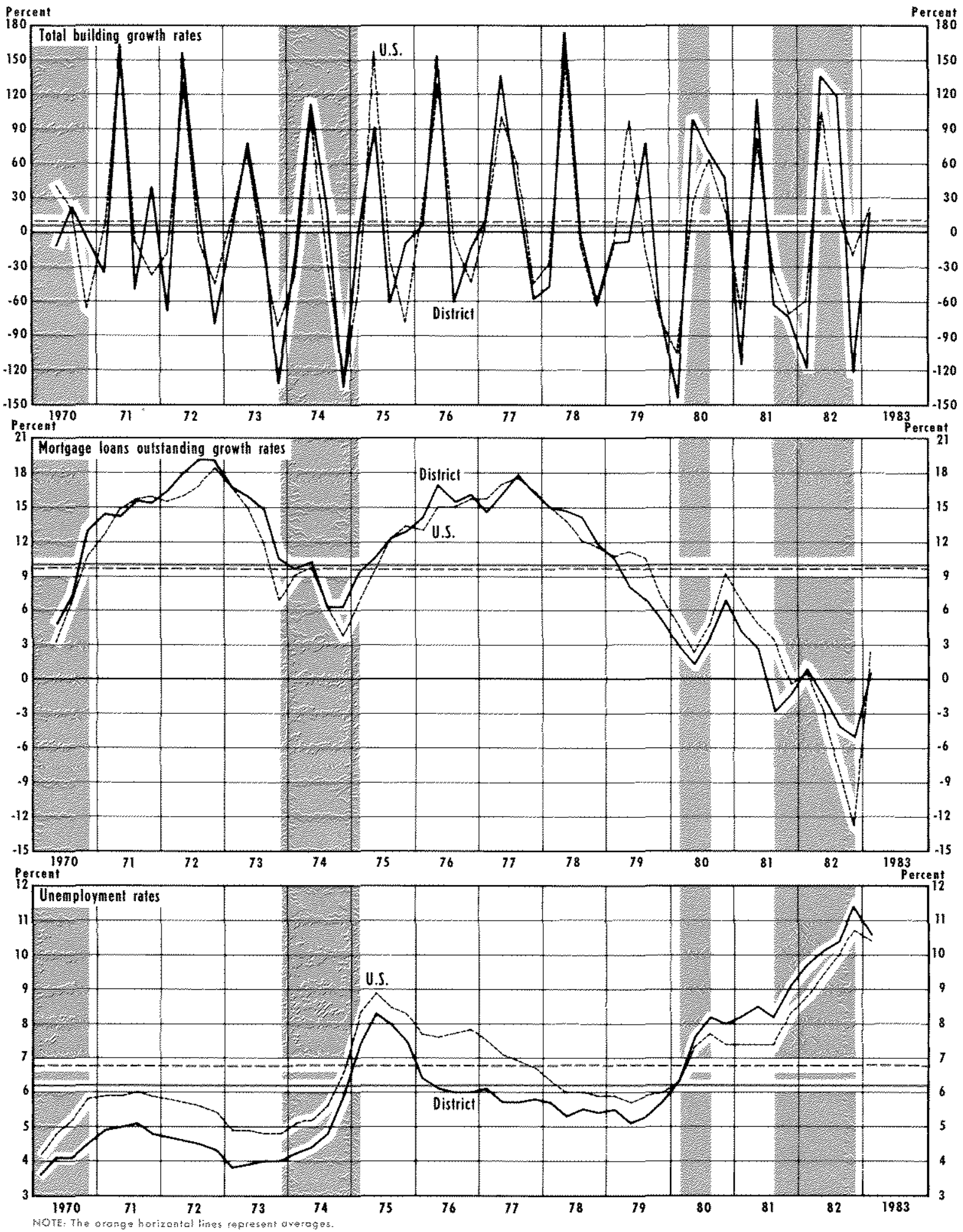

Shaded areas tepresert periods of business recessians. 
Selected Economic Indicators in the United States and the Eighth Federal Reserve District
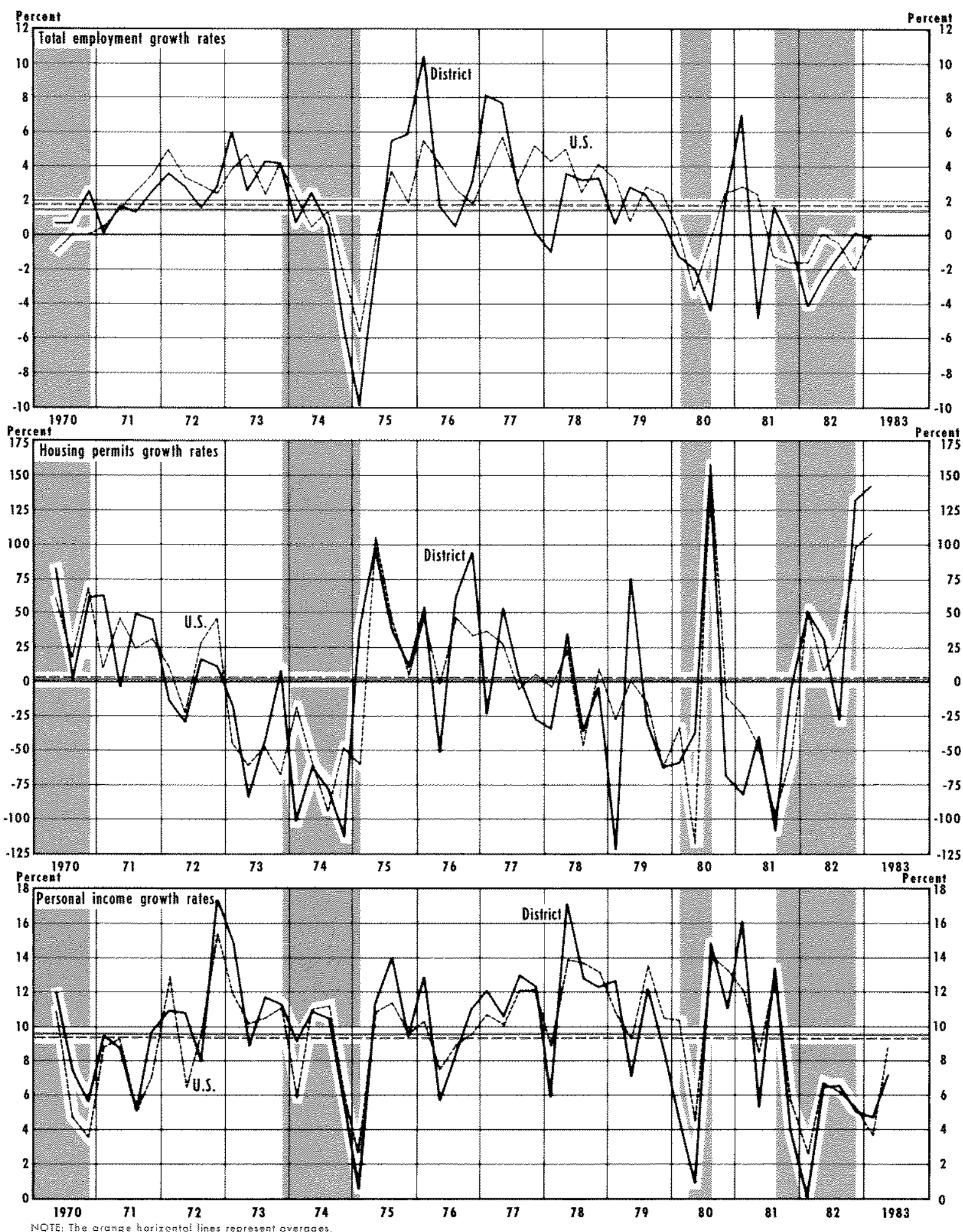


\section{Table 2}

\section{Summary Statistics for Selected Economic Indicators: 1/1970-1/1983}

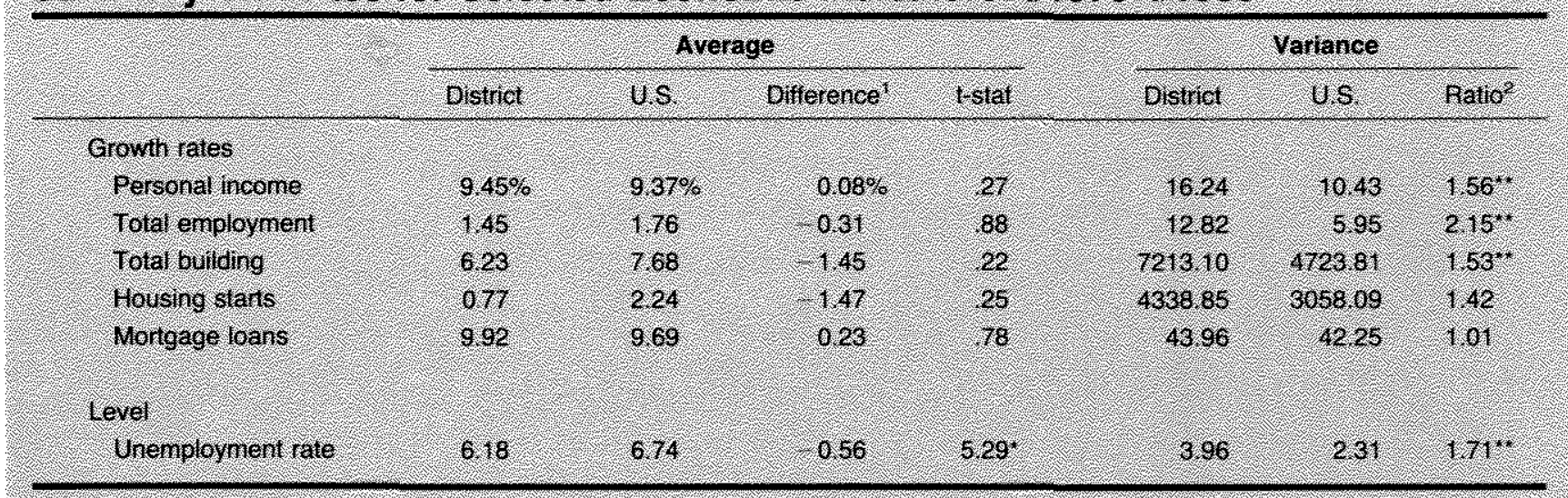

Signiticanty diferent than zeto at the 5 percent level Wsignificantr greater han one at he 5 gercent teve?

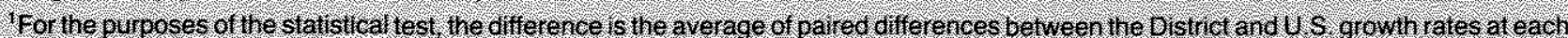
point in tine. As a result the numbers in this colimn nay not cortespond exact) to the diterences be ween the average growth ates $n$ the itst wo coumns

The numbers h this colum are the ratios of the targer to shraler varance

averages. The smaller the sample period, the greater the probability that sizable, albeit meaningless, differences will arise.

These results suggest that the economic performance of the Eighth District, when measured by the growth rates of various indicators as well as the level of the unemployment rate, is somewhat more erratic than that of the nation. At any point in time, the deviations of District indicators from their averages are likely to be greater than deviations of national indicators from their averages. On the other hand, the averages of the growth rates across time for the nation and District are virtually identical indicating that, over the longer run, the economic growth of the District has closely followed the national trend. (See box on page 19.)

\section{Periods of Recession und Lxpansion}

The data in table 3 are similar to those presented in table 2 except that table 3 splits the data into periods of recession and expansion. Analysis of the data can then be used to determine whether the District and national economic indicators, although generally no different on average over long periods, differ significantly during episodes of boom and bust.

With one exception, neither recessions nor expansions appear to affect the relationship between the average levels of the District and national indicators. The differences between the District and national average growth rates are not statistically significant. This holds for both recessions and expansions.

As was the case for the whole period, the one exception is the District's unemployment rate. The data in table 3 indicate that the District's unemployment rate is significantly lower than the national average during expansions. During periods of contraction, however, the District's unemployment rate does not differ significantly, on average, from that of the nation.

The data in table 4 relate the District's "share" of the various measures of economic activity during expansions and recessions. For example, personal income in the District, on average, was 5.75 percent of personal income at the national level during periods of expansion, while it was 5.68 percent of national income during periods of recession. Combined with the data in table 3 , these figures can be used to assess whether recessions are more or less severe in the District than at the national level.

The evidence suggests that the District's "share" of economic activity does not change significantly during recessions. None of the means of the ratios differs significantly from periods of expansion to recession. Further, since none of the ratios of the variances differs significantly between periods of expansion and reces- 


\section{The Relative Performance of the District and the Law of Large Numbers}

Measurenents of economie portormanee at the hation al level hepresent average, of the econonic performanet

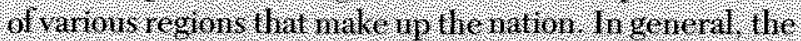

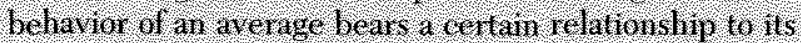

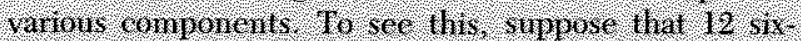

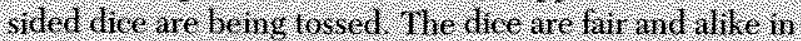
evert resped excent that one of them is terl and We

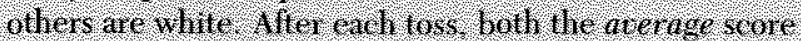

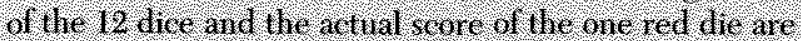
recurled. $\mathbf{I}$ nany hils were condincted. the average

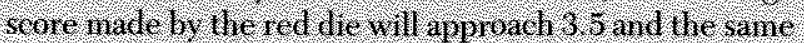
Wil br hie tor he average of lie nean score of lhe 12

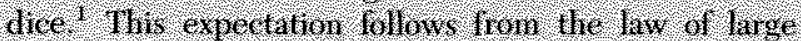
$11011 \mathrm{crs} 2$

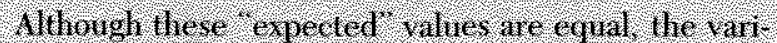

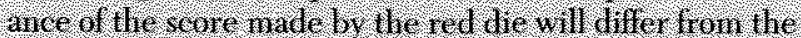

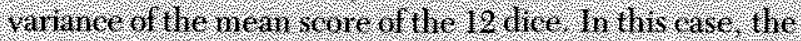
Whance of the seore of the red $91 \mathrm{c}$ will abproad $12 \mathrm{tm}$. that of the wean srone?

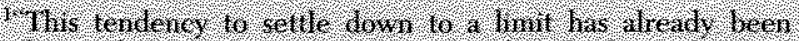

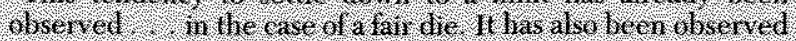

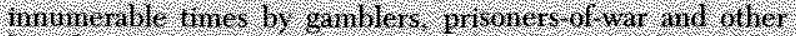

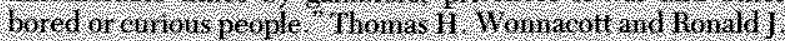

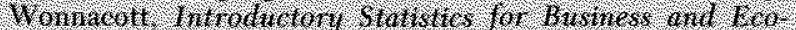

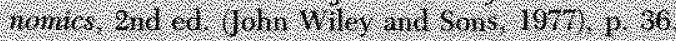

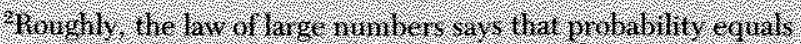

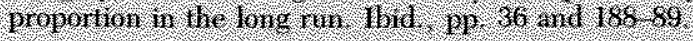

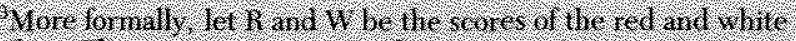

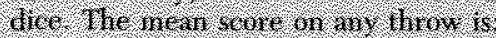

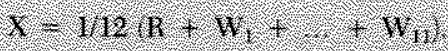

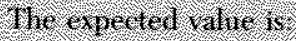

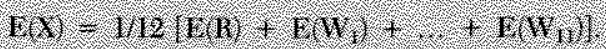

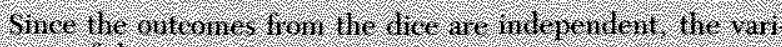

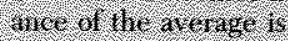

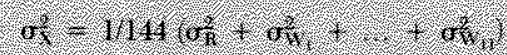

The behavior of the scole of the red de relative to the a verage scome of thre 12 dige is sinilar to that of the cononine performance of Whe District helative to hie

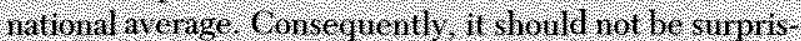

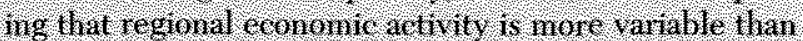
that for the nation as a whle, ever if there is. Withe dillet noe between lhe ate rage levals of economic activ. 16. n the regin and wh the nation.

There ane. however two important diflerences be-

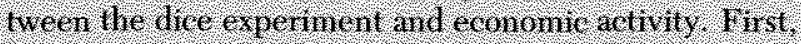

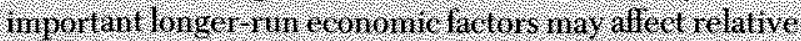
performance, canving the average levels of regional eco home perfonmanee neatines to differ from the nutional

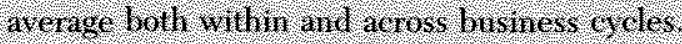

Stecond the level of econonic activit withn any re. gion depends upon that in otler regions. Rusiness crdes carse common novenents in indirators of counomie

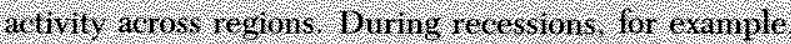
Whe memploy went rite across all regroms will hise. The Dositive contelition that evists between the levels of eco-

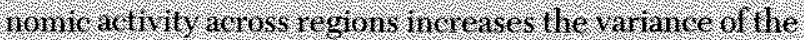
hatlonal average relative to the varinee for ead hegion.

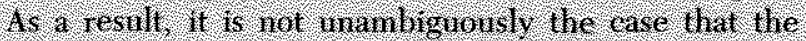
Tarince ol e tommic activit w il any region will be greater

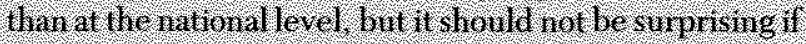
111

It is Worth noing that hie behavior of the Distriets

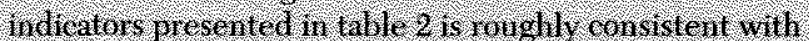
the way we expect hen to be bave relitive to national

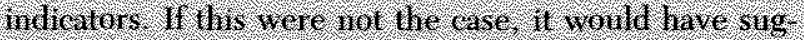

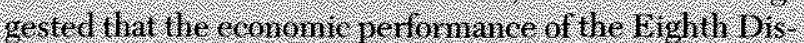

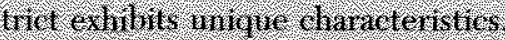

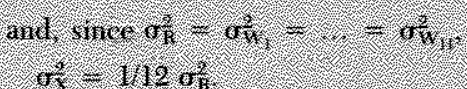




\section{Table 3}

\section{Economic Indicators: 1/1970-1/1983}

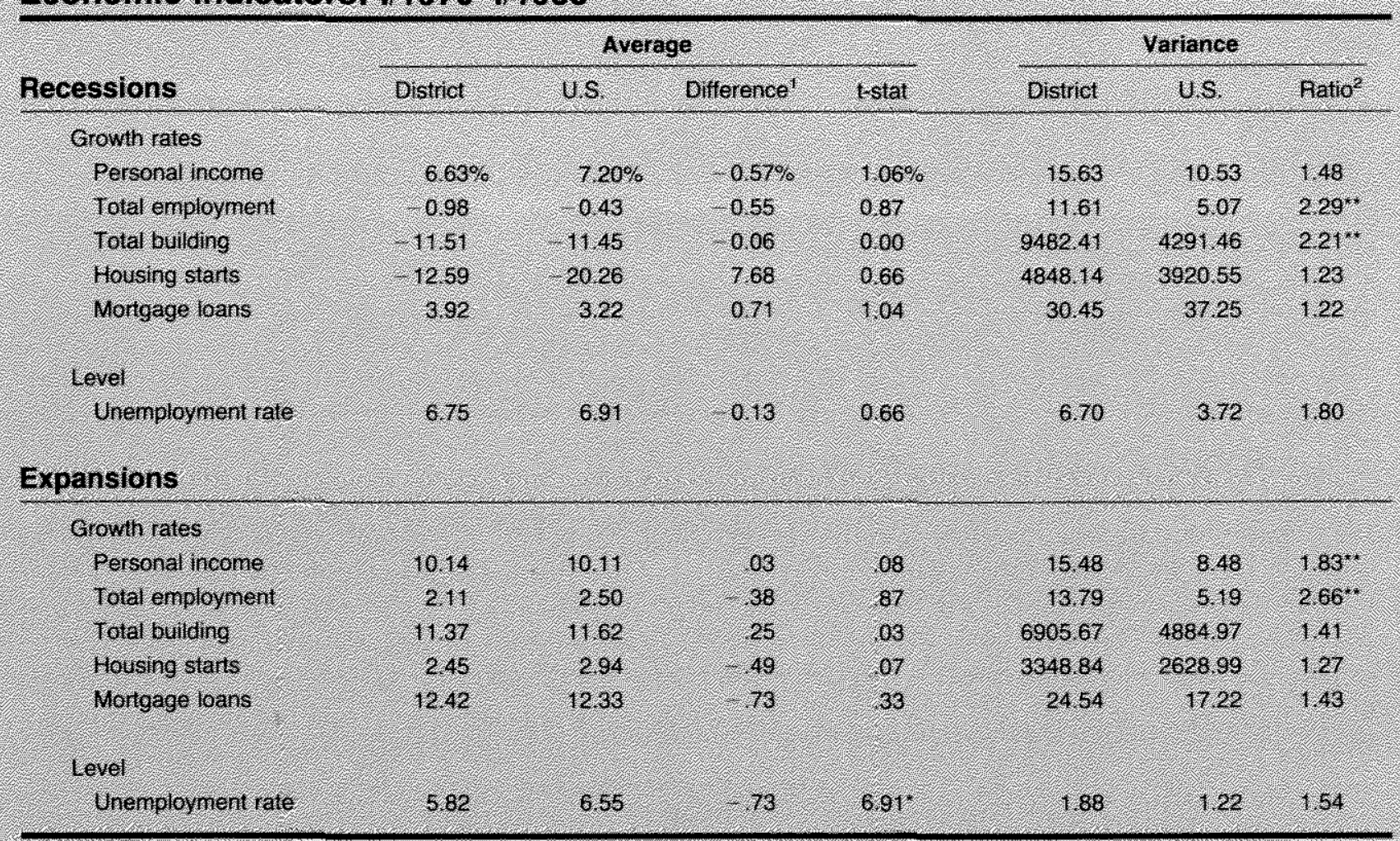

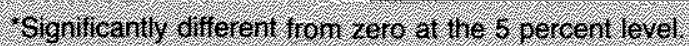

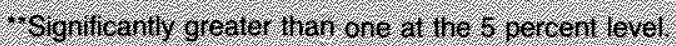

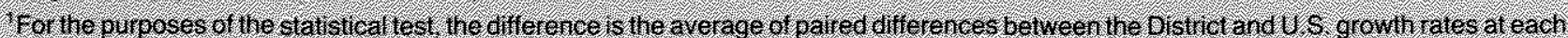

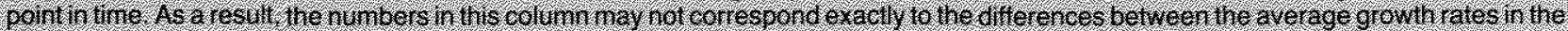
inst wo cotwins.

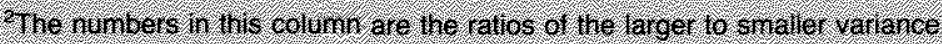

\section{Table 4}

\section{District Indicators as a Percent of National Indicators}

\begin{tabular}{|c|c|c|c|c|c|c|}
\hline & \multicolumn{3}{|c|}{ Average Share } & \multicolumn{3}{|c|}{ Variance } \\
\hline & Expransions & Reeesssions & Diflerence & Evtransugs & recessions & natio \\
\hline Personal income & 875 & 568 & 07 & 0.686 & 0801 & 1,17 \\
\hline Total eniployment & 666 & 660 & 06 & 9720 & 15.801 & 1.62 \\
\hline Total butiding & 410 & 696 & 14 & 9196 & 1634 & 178 \\
\hline Jousing stars & 477 & 466 & 12 & 364,73 & 376.242 & 106 \\
\hline Mrotgage loatts & 5.57 & 550 & 07 & 13.594 & 12.688 & 107 \\
\hline
\end{tabular}


sion, it does not appear that economic activity in the District is significantly more volatile relative to national averages during periods of recession than it is during periods of expansion.

On the whole, the data in tables 3 and 4 indicate that periods of recession are typically no more severe in the District than they are at the national level.

\section{SUTHWNin}

The District's performance, as reflected by the average growth rates of various indicators, has matched that of the nation over the past 14 years. The only exception to this was the level of unemployment. Dnr- ing expansions, the District's unemployment rate, on average, has been significantly below that of the nation, while matching the national average during periods of recession.

Finally, the District's indicators of economic activity tend to be somewhat more volatile than the national indicators. Since the economic activity occurring within the District represents one component of the national average, its variance would generally be expected to exceed that of the nation's. As a result, differences even fairly large ones - that are observed at a point in time between District and national economic indicators are not surprising. Due to their random character, however, it is not possible to predict the timing or direction of the differences beforehand. 